\title{
MSLNL Gene
}

National Cancer Institute

\section{Source}

National Cancer Institute. MSLNL Gene. NCI Thesaurus. Code C127874.

This gene may be involved in cell-matrix adhesion. 